\title{
Projeto de uma Nova Ação de Revisão do Julgado
}

\author{
Lose OMaxia Tesheines
}

Livre-Docente pela Faculdade de Direito da UFRGS, Desembargador aposentado, Professor Orientador do Curso de Mestrado da PUC/RS

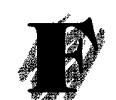

reqüentemente explica-se a coisa julgada como "lex specialis", o que traduz bem a idéia de que ela é como que uma lei especial, diversa da aplicável a todos os demais, ainda que em situação idêntica. A possibilidade de quebra do princípio da isonomia decorre da própria natureza da coisa julgada.

O tratamento desigual de situações iguais aparece pouco nas sentenças relativas a relações privadas, fundadas em fatos transeuntes. Cada caso é um caso, costuma-se dizer. A quebra do princípio da isonomia torna-se aparente e chocante no Direito Público, sobretudo nas relações jurídicas continuativas.

Apontam-se, aqui, casos em que isso ocorre e soluções para diminuir o que se poderia denominar de efeitos perversos da coisa julgada. São propostas que partem de premissas profundamente divergentes sobre os fundamentos do Direito, mas que correm para o mesmo estuário: o aperfeiçoamento de nosso sistema jurídico.

\section{Coisa julgada e isonomia}

A Constituição estabelece que a lei não excluirá da apreciação do Poder Judiciário lesão ou ameaça a direito e não prejudicará o direito adquirido, o ato jurídico perfeito e a coisa julgada (art. 50, XXXV, XXXVI).

Diz PAULO ROBERTO DE OLIVEIRA LIMA, cujas ponderações motivaram o presente trabalho, que a inserção da coisa julgada no texto constitucional operou, em nossa cultura jurídica, um subproduto indesejado, qual seja, a sacralização do instituto que, no seu entender, precisa ser desmistificado. ${ }^{1}$

Apontemos desde logo as razões que o levaram à essa conclusão, chocante à primeira vista.

Em inúmeros casos, o respeito à coisa julgada fere profundamente a isonomia, que é, dos princípios constitucionais, o primeiro que ela consagra (art. 5\%). Assim, por exemplo, funcionários públicos, sofrendo a

1. Contribuição à teoria da coisa julgada. p. 83. 
incidência da mesma lei, propõem ações in dividuais, que vão tendo cada qual a sua sorte. Em face das inevitáveis divergências jurisprudenciais sobre a exata interpretação deste ou daquele dispositivo legal, uns vencem, outros sucumbem. Trabalhando lado a lado, executando a mesma tarefa, submetidos à mesma lei, têm uns seus vencimentos majorados e outros não, situação que pode se estender por anos a fio, face à coisa julgada. O remédio da ação rescisória não cura, porque ela não cabe quando a decisão rescindenda se tiver baseado em texto legal de interpretação controvertida nos tribunais (Súmula no 343 do STF) ou por já haver decorrido o curto prazo de dois anos para sua propositura.

O problema surge com relação a direitos individuais homogêneos, ou seja, os decorrentes de origem comum, que podem, em algumas circunstâncias, originar ações coletivas (Código do Consumidor, art. 81 , III). Direitos individuais homogêneos são direitos iguais, embora de diferentes pessoas. Como a Justiça não faz acepção de pessoas, direitos iguais não devem receber tratamento diferenciado simplesmente porque diversas as pessoas que os titulam.

A desigualdade de tratamento poderia ser evitada se, em lugar de múltiplas (às vezes milhares!) ações individuais, fosse proposta uma única ação coletiva. Todavia, nossa ideologia processual, por uma outra razão, impede que por aí se solucione o problema. Repugna à nossa consciência jurídica estender os efeitos prejudiciais da coisa julgada a interessados que não hajam participado do processo. Por isso mesmo, ao re-

2. Contribuiçăo à teoria da coisa julgada. p. 86 gular a ação coletiva em prol de direitos individuais homogêneos, o Código do Consumidor estabelece que a improcedência do pedido não impede a propositura de ações individuais daqueles que não hajam intervindo no processo como litisconsortes (art 103, § 2º). Dissesse a Lei o contrário, invocar-se-ia a Constituição: a lei não pode excluir da apreciação do Judiciário lesão a direito individual

\section{Alteração da estrutura e dos limites da coisa julgada}

Segundo PAULO ROBERTO DE OLIVEIRA LIMA, a norma constitucional que protege a coisa julgada não impede que se altere sua estrutura e limites, nem a criação de remédio processual hábil a desconstituí-la: "é perfeitamente constitucional a alteração do instituto da coisa julgada, ainda que a mudança implique restringir-lhe a aplicação, a criação de novos instrumentos de seu controle, ou até a sua supressão, em alguns ou todos os casos. ${ }^{2 "}$

Temos por certo que a lei pode alterar o instituto da coisa julgada, restringindo-a em certos casos, aumentando o prazo para a propositura de ação rescisória, estabelecendo novos casos de sentenças nulas, que não transitam em julgado, e criando novos remédios processuais para desconstituí-la. Poderia, porém, eliminar o instituto da coisa julgada?

A pergunta, para ser respondida, deve ser acrescida de outra: poderia a lei eliminar o direito adquirido? A resposta é negativa. $O$ respeito ao direito adquirido e à coisa julgada constitui cláusula pétrea, que não pode sequer ser objeto de emenda constitucional (Constituição, art. 60, $§ 4^{\circ}$, IV). A resposta afirmativa implicaria a possibilidade de edição de leis retroativas, que iriam reger fatos passados, desconstituindo direitos subjetivos e sentenças trânsitas em julgado.

Essa mesma resposta, porém, nos dá o verdadeiro sentido da proteção ao direito adquirido e à coisa julgada: o que se veda é a lei retroativa, desconstitutiva de direitos subjetivos, de atos jurídicos perfeitos e de sentenças que transitaram em julgado. Não se veda - e esse é um dado importante que nas relações continuativas se revise a sentença, por alteração do estado de fato ou de direito, como aliás dispõe o art. 471 do CPC: "Nenhum juiz decidirá novamente as questões já decididas, relativas à mesma lide, salvo: I - se, tratando-se de relação jurídica continuativa, sobreveio modificação no estado de fato ou de direito; caso em que poderá a parte pedir a revisão do que foi estatuído na sentença".

Procurando determinar o sentido da proteção à coisa julgada, diz PAULO ROBERTO DE OLIVEIRA LIMA que:

"editada a sentença sobre determinado caso concreto, é irrelevante que a le disciplinadora do tema seja alterada, dado que a solução prescrita pela sentença, ainda que tenha de produzir seus efeitos no futuro, é intocável, não se lhe podendo opor comando diferente, ainda que editado por lei. O bem jurídico da 'quietude', da 'segurança' e da 'paz' foi valorizado de tal forma

3. Contribuição à teoria da coisa julgada. p. 85. pelo legislador constituinte, que este interditou ao legislador ordinário editar normas agressoras a casos já decididos pelo Judiciário. Nova disciplina jurídica do fato somente incidirá para os casos não julgados. ${ }^{3 "}$

É claro que não passou pela cabeça de PAULO ROBERTO DE OLIVEIRA LIMA suscitar a inconstitucionalidade do art. 471 do CPC; logo ele, preocupado com os excessos a que a proteção da coisa julgada tem levado alguns juristas. A referência feita serve, na verdade, apenas para demonstrar como é fácil, no trato da matéria, parecer que discordam os que concordam, ou que estão de acordo os discordantes. Pedimos que tenham isso em mente os que nos lêem.

\section{Coisa julgada versus princípios da isonomia e da legalidade}

O princípio do respeito à coisa julgada entra, às vezes, em choque com os princípios da isonomia e da legalidade.

No que pertine à isonomia, observa PAULO ROBERTO DE OLIVEIRA LIMA que nada mais magoa, do que o tratamento discriminatório. Até as crianças, nos lares e nos colégios, exigem tratamento isonômico. A própria justiça é, aliás, definida como tratamento igual dos iguais.

"Nestas circunstâncias", diz, "o sistema jurídico não pode deixar sem remédio adequado casos de julgamentos díspares que revoltam os protagonistas, deixam perplexa a sociedade e desorganizam o meio social. 
$\mathrm{Na}$ questão do pretenso direito adquirido dos empregados e servidores públicos, ao índice de reajuste de $84,32 \%$, em março de 1990, o instituto da coisa julgada garantiu que muitos servidores gozassem do reajuste, vedando igual vantagem a outros tantos. Em alguns casos, a sorte pô-los uns e outros juntos na mesma sala.

$\mathrm{Na}$ questão do aumento da alíquota do imposto de importação sobre carros, onde alguns julgados tomaram como data da incidência a do desembaraço da mercadoria e outros consideraram-na a da contratação da importação, o instituto da coisa julgada garantiu a uns a importação com a alíquota antiga, obrigando outros a pagarem a nova, a despeito de todos terem a mesma situação jurídica, inclusive no que pertine à data da contratação da importação e ao desembaraço das mercadorias.

$O$ elenco de casos poderia se estender por páginas a fio, mesmo que somente se desse atenção aos numerosos e de repercussão nacional." 4

A violação do princípio da isonomia demonstra-se com fatos; a violação do princípio da legalidade exige considerações jurídicas.

\section{Dualidade do Direito}

Observa PAULO ROBERTO OLIVEIRA LIMA que, por vezes, equívocos remotos, em que incide a ciência quando da definição de seus postulados básicos, implicam a impossibilidade de solver dificuldades particulares que se apresentam na

\footnotetext{
4. Contribuição à teoria da coisa julgada. p. 110.

5. Contribuiçăo à teoria da coisa julgada. p. 87
}

Revista da Faculdade de Direito da UFRGS, v. 17, 1999 ponta dos derradeiros ramos da árvore lógica que representa o sistema. ${ }^{5}$

No caso do processo civil, esse equívoco consistiria na adoção, pelos processualistas, do princípio da dualidade do direito, em vez do princípio da unicidade, consagrado pelo Constituição. Dele é que decorreriam os efeitos indesejáveis da coisa julgada.

É princípio assente que compete ao Poder Legislativo a criação do Direito, isto é, a alteração da ordem jurídica. Ao Judiciário compete tão-só aplicar as normas estabelecidas pelo legislador. É certo que há normas que resultam do costume, da eqüidade e dos principais vetores do sistema, identificados a partir da análise do conjunto normativo. Contudo, ainda que explicitadas por sentença, não são por ela criadas.

A incidência da norma é prévia, automática e infalível. Ao Judiciário compete aplicar a norma que incidiu, mediante provocação do interessado, sempre que este argüir eventual descoincidência entre $a$ incidência e a aplicação.

Malgrado tais conceitos sejam aceitos pela expressiva maioria dos juristas, ensina-se também que a sentença, aplicando a lei, tem força criativa própria, o que permite ter havido incidência sem haver aplicação, não ter havido incidência e haver aplicação e coincidirem aplicação e incidência. Afirma-se que a sentença constitui ato de vontade, tem força criativa própria, o que implica a existência de duas ordens jurídi- cas: uma fundada na lei e outra fundada na sentença.

Segundo PAULO ROBERTO, aceitar essa dualidade implica abdicar de postulados fundamentais, quais sejam, a isonomia, a legalidade, a divisão de poderes e a democracia. ${ }^{6}$

A visão dual é consagrada pelo Có digo de Processo Civil, ao afirmar que a sentença tem força de lei (art. 468). Haveria, assim, duas ordens jurídicas, uma fundada na lei editada pelo Poder Legislativo e aplicada pelos destinatários públicos e privados; outra criada e aplicada pelo Judiciário, não servindo a primeira senão para ministrar subsídios ao julgador, no momento da edição das normas componentes da segunda ordem.

Daí o prestígio da coisa julgada.

"A adoção da tese da unicidade do Direito conduz à conclusão oposta, qual seja, a de ser a sentença ato exclusivamente intelectivo, consistente na aplicação do direito objetivo, revelado pelo Poder Legislativo, ao caso concreto decidido. A sentença, aqui, é mero processo de cognição e de adequação lógica, sendo vazia do elemento 'vontade'. Ao julgar a lide, o Estado-juiz não exerce qualquer opção axiológica, nem reavalia as circunstâncias particulares do caso concreto, salvo no que for essencial para identificar qual a regra jurídica incidente sobre os fatos e quais as conseqüências decorrentes desta incidência."

6. Contribuição à teoria da coisa julgada. p. 94.

8. Contribuição à teoria da coisa julgada. p. 105.
Prossegue PAULO ROBERTO DE OLIVEIRA LIMA, afirmando que a tese da dualidade do Direito se vincula necessariamente ao reconhecimento da natureza volitiva da sentença, e a da unicidade, ao de sua natureza meramente intelectiva. Se nosso sistema jurídico se funda na lei (Constituição, art. 5ำ II), não pode a sentença instituir obrigações. A dualidade, além de ser incompatível com os princípios da isonomia e da legalidade, também o é com a democracia. Se todo poder emana do povo, em cujo nome deve ser exercido, não pode o Estado-juiz, ao julgar a lide, editar outro comando que não seja o da lei.

"No Brasil, onde a Carta Política é formal e rígida, consagrando explicitamente a democracia, a isonomia e a legalidade como cânones fundamentais máximos do Estado de direito, inexiste espaço lógico e político onde possa medrar a tese da dualidade. ${ }^{\prime \prime}$

\section{Unicidade do Direito}

Pelo contrário, prossegue PAULO ROBERTO DE OLIVEIRA LIMA, a tese da unicidade compatibiliza-se perfeitamente com a democracia, com os princípios constitucionais da isonomia e da legalidade, com a natureza exclusivamente intelectiva da sentença e com o clássico sistema de freios e contrapesos que caracteriza a tripartição constitucional dos poderes, preconizada por MONTESQUIEU e consagrada por nossa Constituição. 
E conclui:

"a opção pela unicidade do Direito e o conseqüente reconhecimento da possibilidade da sentença errada e injusta obrigam o sistema a adotar remédio jurídico eficaz para a sua retificação. Essa é a principal repercussão da adoção da tese da unicidade sobre o instituto da coisa julgada. A unicidade do Direito reclama um enfraquecimento da imutabilidade das decisões definitivas, tornando-as modificáveis. $\mathrm{Na}$ quebra de braço entre a coisa julgada, de um lado, e a legalidade e a isonomia, do outro lado, a primeira cede o passo às segundas."

\section{Um remédio mais amplo do que a rescisória}

A seguir, demonstra o Autor a insuficiência da rescisória, para restabelecer unidade do Direito, seja por haver a sen tença rescindenda adotado tese "razoável", seja porque decorrido o prazo para sua propositura.

Preconiza a criação de um remédio jurídico próprio, mais amplo que a ação rescisória e diz:

"Enquanto não vem este remédio jurídico-processual a ser disciplinado em lei ordinária, nada impede, ao contrário tudo aconselha, urgente alteração na postura do Poder Judiciário para que se avance no sentido de admitir nova propositura de idêntica ação, ainda que tal implique literal violação da lei processual instituidora da coisa julgada, sempre que a manutenção do

\section{Contribuição à teoria da coisa julgada. p. 106.}

10. Contribuição à teoria da coisa julgada. pp. 109. julgamento original implicar o sacrifício do princípio da legalidade ou da isonomia. ${ }^{10 "}$

PAULO ROBERTO DE OLIVEIRA LIMA observou bem que o tema por ele posto põe em cheque concepções jurídicas fundamentais, que se encontram "na raiz da árvore", com "conseqüências manifestadas nas pontas das ramas mais delgadas".

\section{A jurisprudência como fonte do Direito}

De nossa parte, entendemos que o Direito é o que é, não algo que deveria ser. É com esta visão de realidade que admitimos ser a jurisprudência, também ela, fonte do Direito, ao lado da lei e do direito consuetudinário. Nem sequer estamos a nos referir à eventual sentença injusta, que nega obrigação existente ou afirma direito subjetivo inexistente. Admitimos a criação judicial do Direito, no sentido de que surgem, no sistema jurídico, normas gerais e abstratas que devem sua origem ao labor dos tribunais, e não diretamente ao legislador.

A mesma visão de realidade nos leva a afirmar o caráter volitivo do comando contido na sentença. A vontade do juiz é psicologicamente ineliminável: quando ele condena, condena porque quer, ainda que queira em obediência ao ordenamento jurídico. Coactus voluit tamen voluit (quis, porque coagido, mas quis). Não vinga a frágil desculpa de que foi a lei que quis. Essa é a realidade do Direito, embora não coincida com o esquema lógico dos juristas, que imaginam um sistema automático de incidên- cia de normas jurídicas, previamente estabelecidas, sobre fatos ocorridos posteriormente. Não raras vezes, essa norma que previamente incidiu apenas passou a ter existência com a prolação da sentença.

Num sistema ideal, o juiz aplicaria sempre a lei que incidiu. Mas quem diz que vivemos num mundo ideal?

Quando o Código de Processo Civil enuncia que a sentença faz lei entre as partes, nada mais faz do que reconhecer uma realidade, que talvez nem sequer fosse a desejada pelo legislador

Entendemos, pois, que são fontes do Direito: a lei, a jurisprudência e o costume.

Historicamente, o costume precedeu à jurisprudência que, por sua vez, precedeu à lei, como hoje a entendemos, isto é, como norma geral e abstrata emitida pelo Estado. Numa ordenação de importância decrescente, a lei, hoje, se superpõe à jurisprudência e esta, ao costume.

A sociedade constitui-se produzindo normas costumeiras. Daí a antigüidade do costume. Direito primitivo é Direito costu meiro. $\mathrm{O}$ jus, contemporâneo da sociedade, de que se fala na assertiva ubi societas, ibi jus (onde há sociedade, aí há direito), é, pois, Direito, jus costumeiro.

Ao organizar-se em Estado, a sociedade passa a produzir normas jurisprudenciais e legais. Pode-se, então, dizer que as normas costumeiras são produzidas pela sociedade; a jurisprudência e a lei, pelo Estado.

O costume é de produção lenta, lo cal e de difícil constatação. Ao se organizar em Estado, a sociedade o constitui como um sistema de produção de normas jurídicas. Produzem-se, então, normas legais e jurisprudenciais, com maior rapidez, eficiência e racionalidade, que constituem emergências do sistema.

A lei, sobretudo a lei, pode ser editada rapidamente, sua existência pode ser facilmente determinada e sua vigência pode-se estender sobre imensos territórios, regendo a conduta de indivíduos que, distantes uns dos outros, jamais poderiam gerar costumes comuns a todos.

\section{Produção de normas jurídicas pelos três Poderes do Estado}

Modernamente, o Estado apresentase tripartido em três Poderes: o Legislativo, o Executivo e o Judiciário. Este apresentase, assim, como subsistema do sistema de produção de normas jurídicas. A sociedade continua a produzir normas costumeiras, mas estas perdem quase toda a sua importância. O que releva, quase sempre, são as normas produzidas pelo Estado, através de seus três Poderes. Todos eles produzem normas gerais e abstratas, sobretudo o Legislativo.

Ao Executivo e ao Judiciário caberia, em princípio, a produção de normas concretas. Todavia, isso está longe de refletir a realidade. O Poder Executivo produz, em larga escala, também ele, normas gerais e abstratas. O Poder Judiciário sim produz especialmente normas concretas, mas com a virtualidade de se tornarem gerais, através do fenômeno denominado jurisprudência. 
De acordo com a Constituição (art. $2^{2}$ ), os três Poderes são independentes e harmônicos entre si.

Em nosso sistema jurídico, o Judiciário é relativamente autônomo. Apresentase, por um lado, como um superpoder, pois tem competência para julgar e tornar sem efeito os atos da Administração e até para julgar e declarar inconstitucionais as próprias leis que é chamado a aplicar. Apresenta-se, por outro lado, com um subpoder, pois é organizado pelo Legislativo e deve obediência à lei. É sobretudo através do poder de reformar a Constituição que se afirma a primazia do Congresso Nacional.

Subordinado à lei, exerce o Poder Judiciário uma atividade de segunda categoria, pois é a lei que fixa os fins que os juízes precisam afanosamente descobrir buscar.

Nosso sistema, fundado em leis ge rais e abstratas, é, por isso mesmo, um sistema flexível. A hermenêutica abre amplo espaço para a adequação da norma geral ao caso concreto, afastando-se injustiças decorrentes da imprevisão do legislador relativamente às peculiaridades de cada caso. Para isso, aliás, existem os juízes: para que cada um possa ter examinado o seu caso, com as suas circunstâncias próprias.

Nenhuma dúvida há de que nosso sistema jurídico se funda na supremacia da lei. Há de se afastar, contudo, o dogma da onipotência do legislador, ainda que este se apresente como constituinte. A sociedade segrega normas jurídicas, sob a forma de costumes, fonte do Direito que perdeu muito, mas não por completo, a sua importância.
Hoje, a produção de normas jurídicas, diretamente pela sociedade, independentemente e contra o aparelho estatal, apresenta-se sobretudo sob a forma de rejeição. Na verdade, as leis precisam ser acei tas pela sociedade. Não basta que as faça o legislador. Daí o interessantíssimo fenômeno, com que volta e meia se defrontam os Tribunais, das leis que não são leis, das leis que o são nos livros, mas não na vida real. O dogma da onipotência do legislador é, primeiro que tudo, falso, e serve, em segun do lugar, para justificar qualquer absurdo e toda injustiça provenientes dos detentores do poder político.

Entre o Legislativo, que produz as leis, e a sociedade, que as recebe ou rejeita, encontram-se os juízes, chamados a aplicar as leis que a sociedade aceitou e os costumes que se conformam com as leis. Os juízes são governo e são povo. São tanto mais governo quanto mais alto o degrau em que se encontram na hierarquia do Poder Judiciário. Tanto mais povo, quanto mais dele se aproximam, por suas origens, por suas idéias, por seus sentimentos e por seu comportamento. Ocupando posição intercalar, são chamados a atender e a fazer cumprir as determinações do alto, mas também a ouvir e a atender as aspirações que vêm do subsolo do corpo social.

Nessa posição ambígua de órgãos de governo e voz do povo, os juízes e o Poder Judiciário segregam a jurisprudência que, é claro, não se confunde com o mero precedente, isolado, que freqüentemente não representa senão uma deturpação jurídica, produto da má cabeça ou de um mau momento, de algum Juiz ou Tribunal.
Das leis, normas gerais e abstratas, deduzem-se as normas jurídicas concretas, que se aplicam a cada caso. Em sentido inverso, das normas concretas, produzidas pelos Tribunais, induzem-se normas gerais e abstratas e eis, então, aí, o fenômeno da jurisprudência.

De um ponto de vista sociológico, é certo que a jurisprudência é fonte do Direito. Seria fácil apontar normas gerais que dela emergiram, ainda que contra a lei. A negação, à jurisprudência, do caráter de fonte do Direito, tem evidente cunho ideológico. Nega-se a produção de Direito pelos Tribunais, a fim de que eles não sejam tentados a produzi-lo.

Cabe perguntar, então, se, de um ponto de vista estritamente jurídico, mais ideal do que real, a jurisprudência deve ou não ser havida como fonte do Direito. A pergunta pode ser posta de uma forma mais brutal, indagando-se, enfim, se juízes e tribunais podem decidir contra a lei ou, em latim, para ser menos chocante, se eles podem decidir contra legem. Efetivamente, não há nenhuma dificuldade teórica em se admitir a jurisprudência secundum legem ou praeter legem. Todo o problema se põe, de maneira viva e dolorida, em face da jurisprudência contra legem.

\section{Primazia da lei}

Não há dúvida quanto à primazia da lei em nosso sistema jurídico. Primazia sim não monopólio. As leis emitidas no passado freqüentemente vigem no presente em descompasso com as circunstâncias em que são chamadas a atuar. Há também as hipóteses de leis monstruosas e de leis tolas, e seria monstruoso e constituiria tolice exigir-se que os tribunais as aplicassem tal como foram editadas. Há, ainda, o caso das leis que a sociedade rejeitou e que, por isso, não podem ser aplicadas. Há, sobretudo, a lição que os séculos nos legaram, no sentido de que o Direito não se contém todo nas leis. Há, pois, que se admitir a jurisprudência como fonte do Direito. Introduz-se, assim, uma certa desordem no sistema jurídico, que deixa de ser monolítico. Ressalte-se, porém, que uma ordem perfeita e absoluta não passa de um sonho, ou melhor, de um pesadelo tecnocrático, tendo mais a ver com os delírios das idéias do que com as realidades da vida.

O Judiciário é um Poder. Exerce atividade de governo. Incumbe-lhe dizer, em cada caso, o que é direito. Cabe-lhe exercer uma atividade como que imunológica, rejeitando as leis inconstitucionais bem como declarando a rejeição social de algumas normas. Produz a jurisprudência, que, como a lei, é fonte do Direito. Tudo isso é verdade e, contudo, é preciso que se apregoe a supremacia da lei e se pregue a subordinação do Juiz à lei. Investido na sua função, na forma e em virtude da lei, deve o Juiz fidelidade ao sistema jurídico que o constituiu como órgão seu.. Não se pretenda libertar o Juiz do dever de obediência à lei, ainda que em nome da Justiça, porque a liberdade do Juiz submete os jurisdicionados ao arbítrio e aos caprichos de sua autoridade.

Prendem-se as feras, para que não periclitem a vida de todos.

Pode o Juiz, em especiais circunstâncias, pôr entre parênteses alguma norma 
aparentemente jurídica. Deve, porém, fidelidade ao sistema jurídico que o constituiu, sob pena de trair a missão que lhe foi confiada. Não se prega uma submissão tola, nem cega, mas uma obediência inteligente e voluntária, mais aceita como necessidade social do que imposta por coerção autoritária. Se desaparece o dever de obedecer, em consciência, tudo se reduz a um jogo de forças. Mandam os mais fortes, submetem-se os vencidos e, ao termo de tudo, não se tem nem lei, nem Direito, nem Justiça, mas violência, arbítrio e arrogância.

Como se observa, o reconhecimento da jurisprudência como fonte do Direito de forma alguma nos leva a pregar a desobediência à lei. E, muito menos, nos conduz a nos conformarmos com a quebra do princípio da isonomia decorrente de divergências jurisprudenciais. Aliás, se a divergência não se resolve nunca, o que exatamente não há é criação jurisprudencial do Direito.

Temos, pois, do Direito uma visão diferente da exposta por Paulo Roberto de Oliveira Lima. Coincidimos, porém, na necessidade de reformas no instituto da coisa julgada.

Examinaremos as suas propostas e concluiremos apresentando a nossa.

\section{A primeira proposta de Paulo Roberto de Oliveira Lima}

A primeira proposta de PAULO ROBERTO é no sentido de excluir a ofensa à coisa julgada como fundamento para a rescisão da sentença, declarando-a nula. Em embargos à execução fundada em sentença poderia o executado alegar: "nulidade da sentença, por ofensa à coisa julgada, salvo se tal alegação já houver sido objeto de exa me no processo de conhecimento".

Em outras palavras, a sentença proferida com ofensa à coisa julgada deixaria de integrar a categoria das sentenças meramente rescindíveis, para integrar a das sentenças nulas, na companhia da proferida em processo que correu à revelia de réu não citado ou nulamente citado, caso em que a nulidade pode ser decretada em embargos à execução, ou em outro processo (querela nullitatis).

Estamos de pleno acordo, mesmo nós que sustentamos, em face do direito posto, a prevalência da segunda decisão, pois meramente rescindível. Mais ainda deverão estar de acordo os que sustentam a prevalência da primeira, sobretudo os que até afirmam não ocorrer decadência do direito de rescindir a sentença, no caso de ofensa à coisa julgada.

A alegabilidadade em embargos à execução é conseqüência lógica da nulida de. Aliás, bastaria a inclusão da coisa julgada como matéria de embargos para se concluir pela nulidade, como ocorre com a sentença nula por falta ou vício da citação em processo de conhecimento que correu à revelia.

No Direito português, constitui fundamento para a oposição à execução de sentença a existência de caso julgado anterior à sentença que se executa (Código de Processo Civil, art. 813, f).

\section{A segunda proposta}

Outra proposta acaba com a ação rescisória por violação de literal disposição de lei, instituindo, em seu lugar, ação revisional da coisa julgada, nos seguintes termos:
"Art. 1ํ A revisão da coisa julgada material, através da presente ação, poderá ser requerida pelo interessado quando a decisão atacada:

I - violar literal disposição de Lei;

II - contrariar a súmula dos tribunais superiores;

III - houver adotado no caso concreto interpretação de regra jurídica diversa da que haja sido aplicada em outra oportunidade, a questão igual.

Art. 2ํA A petição inicial será elaborada com a observância dos requisitos essenciais do art. 282, devendo o autor:

I - cumular ao pedido de revisão o de novo julgamento da causa;

II - depositar a importância de $10 \%$ (dez por cento) sobre o valor da causa, a título de multa, revertida em proveito do réu, caso a ação seja julgada improcedente;

III - comprovar, se for o caso, a existência e a vigência da súmula contrariada, ou a divergência jurisprudencial argüida, demonstrando a identidade entre a questão a ser revista e o paradigma;

$\S 1^{\circ}$ Não se plica o disposto no inciso II à União, ao Estado, ao Município e ao Ministério Público.

$\S 2^{\circ}$ Havendo mudança do valor da causa, por determinação do juiz, seja de ofício, seja em face de incidente de impugnação intentado pelo réu, o autor será intimado para complementar o valor do depósito, em 05 (cinco) dias, sob pena de ser o feito extinto, sem julgamento do mérito.

11. Contribuiçăo à teoria da coisa julgada. pp. 165-6.
Art. 3ำ Tem legitimidade para propor a ação:

I - quem foi parte no processo ou seu sucessor;

II - o terceiro juridicamente interes. sado;

III - o Ministério Público.

Art. $4^{\circ}$ A ação revisional da coisa julgada deve ser proposta no primeiro grau de jurisdição, ainda que o julgado a ser revisto tenha sido prolatado em instância superior, salvo se se tratar de causa de conhecimento originário dos tribunais, caso em que também a ação revisional deve ne. les ser ajuizada.

Art. $5^{\circ}$ No julgamento do mérito da ação revisional, o juiz não fica vinculado à solução adotada no paradigma.

Art. 6 A ação revisional da coisa julgada não prescreve senão quando prescrito o direito subjetivo objeto da decisão atacada.

Art. $7^{\circ} \mathrm{A}$ ação revisional não suspende a execução da sentença.

Art. 8ำ Não enseja ação revisional da coisa julgada mero reexame da prova pro. duzida.

Art. 9 Julgada procedente a ação revisional da coisa julgada, a sentença então prolatada substitui integralmente o julgado revisto.

Art. 10. Aplica-se à ação revisional da coisa julgada o procedimento ordinário. ${ }^{11}$ " 
O Autor justifica a sua proposta, dizendo que a inevitável opção pela tese da unicidade do Direito implica estruturar o instituto da coisa julgada com maior plasticidade, permitindo a revisão do julgado que haja declarado direito subjetivo efetivamente inexistente. A modificação do julgado já é admitida pela atual ação rescisória e, mais amplamente, pela revisão criminal, mas ainda é excessivo o nível de imutabilidade conferido à coisa julgada pela lei processual. $O$ princípio da legalidade não pode ser sacrificado em homenagem à coisa julgada, tampouco o princípio da isonomia. No choque entre eles, a imutabilidade tem de ceder passagem àqueles princípios basilares do constitucionalismo nacional.

Impõe-se a revisão da sentença contrária à jurisprudência, inclusive em face de mudança de orientação jurisprudencial. É inadmissível a aplicação de duas regras ju rídicas diferentes, extraídas da interpreta ção de um mesmo dispositivo legal, em frontal desrespeito aos princípios constitu cionais da isonomia e da legalidade. $O$ respeito da sociedade civil ao Direito, enquanto processo social de adaptação, prestígio do Judiciário, enquanto instituição encarregada de realizar o bem supremo da Justiça, passa necessariamente pela urgente adoção da revisibilidade da sentença anti-isonômica. $O$ limite temporal para $o$ exercício da ação deve coincidir com o termo final do prazo prescricional para o exercício do próprio direito subjetivo, cuja alegação ensejou a ida ao Judiciário, para que o processo não seja fonte de direito subnão tenha força criativa própria. ${ }^{12}$

"Não se trata de revisar matéria de fato, mas da adoção de teses objetivas quanto ao exato entendimento da lei. Por exemplo, se o prazo prescricional das ações que visem exigir o pagamento das contribuições previdenciárias é qüinqüenal ou trintenário se é inconstitucional o ato que proíbe o uso de películas anti-reflexivas nas áreas envidraçadas dos automóveis; se a mudança do regime celetista para o estatutário enseja o saque dos depósitos vinculados ao fundo de garantia por tempo de serviço; se agride à isonomia a permissão da importação de automóveis (ou pneus) novos e a proibição de usados; se é inconstitucional a exigência de idade mínima para fazer de terminado concurso; se é devido o reajuste de $147,06 \%$ aos aposentados, em setembro de 1991; se é direito do promitente com prador, que não tenha registrado o pré-contrato de compra, excluir da penhora o bem prometido em venda, quando executado o promitente vendedor; se é legal a imposição pelo Estado, aos indivíduos, do uso dos cintos de segurança. ${ }^{13}$ "

Observamos, desde logo, que a ação revisional a que se refere o art. 471, I, do Código de Processo Civil (revisão de sentença relativa a relação jurídica continuativa, com fundamento em modificação no estado de fato ou de direito). Trata-se, na verdade, de ação rescisória, tal jetivo, ou por outra, para que a sentença pretendida não tem a natureza da ação

12. Contribuição à teoria da coisa julgada. pp. 111-24.

13. Contribuiçăo à teoria da coisa julgada. pp. 115-6.

Revista da Faculdade de Direito da UFRGS, v. 17, 1999 como hoje a concebemos, embora com diferente regulamentação jurídica.

A violação de literal disposição de lei já é, hoje, fundamento para a rescisão de sentença.

A contrariedade a súmula dos tribunais superiores pode ser vista como um caso especial de violação de literal disposição de lei: violação de lei, tal como revelada pelos tribunais superiores, através de súmula. De um modo mais realista, pode-se ver, no dispositivo proposto, a consagração das súmulas dos tribunais superiores como fonte do Direito, contrariamente à tese da unicidade, tão vigorosamente sustentada pelo proponente.

$O$ inc. III faz da divergência jurisprudencial, que já é fundamento do recurso especial, causa para a rescisão da sentença, a qualquer tempo, com resultados a nosso ver inadmissíveis. Suponha-se a hipótese de servidor público que esteja, por força de sentença, a receber vantagem negada a outros, também por sentença. Como a Administração lhe vem pagando regularmente a vantagem, não há que se falar em prescrição. Nos termos da proposta, não há outro prazo para o pedido de rescisão. Decorridos cinco, dez, quinze ou vinte anos, a Administração pede a "revisão" da sentença, obtendo êxito. $O$ servidor teria de repetir o que recebera durante todos esses anos! O pior é que tal ação não asseguraria o desejado tratamento isonômico, porque (são coisas que ocorrem) poderia a Administração propor a ação "revisional" contra alguns, mas não contra todos os que, embora por sentença, houvessem percebido "vantagem indevida".

\section{A terceira proposta}

PAULO ROBERTO DE OLIVEIRA

LIMA quer transformar em afirmação a negação constante do art. 469 do CPC, para dizer que fazem coisa julgada: a verdade dos fatos, estabelecida como fundamento da sentença; a apreciação de todas as questões decididas, relativas ao caso concreto, que constituam premissa necessária da conclusão.

Trata-se, pois, de alterar os limites objetivos da coisa julgada, para que não se limitem ao comando contido na sentença, mas se estendam aos seus fundamentos.

Entende o Autor não ter sido feliz a opção do Código.

"Restringir a eficácia da coisa julgada ao dispositivo significa abandonar parte do resultado útil do processo, desprezar significativo trabalho produzido pelo Judiciário e multiplicar as possibilidades de decisões conflitantes, militando em desfavor da isonomia e ampliando as oportunidades de gerar perplexidades e desconfianças na atuação do Judiciário. Houvesse, em compensação destas desvantagens, alguma vantagem na restrição da abrangência dos limites objetivos da coisa julgada, e seria o caso de o jurista promover cuidadoso exame do conjunto de ganhos e perdas, com o objetivo de fazer a opção que melhor atendesse às necessidades do sistema jurídico. Ironicamente, porém, inexiste qualquer desvantagem na ampliação. Contudo, o legislador escolheu a restrição máxima. É tempo de mudar de rumo. O Judiciário atravancado de feitos, a necessidade da rápida solução dos litígios, a insuficiência dos 
juízos para atender com eficiência a massa de demandas, principalmente diante da chamada litigiosidade latente e reprimida, a necessidade óbvia da uniformização das soluções, tudo aponta para a máxima ampliação dos limites da coisa julgada. ${ }^{14 "}$

Não parece razoável ao Autor que, no caso, por exemplo, de duas ações propostas com fundamento no mesmo acidente de trânsito, uma primeira sentença julgue improcedente a ação de $A$ contra $B$, imputando toda a culpa ao próprio demandante, e uma sentença julgue improcedente também a ação de $B$ contra $A$, dizendo que este não teve culpa alguma ou afirmando, quiçá, que nem sequer houve abalroamento. Nesse caso, como se sabe, há contradição lógica entre as sentenças, mas não contradição jurídica.

A proposta coerentemente acaba com a ação declaratória incidental. Segundo o proponente, a nova redação do art. 469 melhor o harmonizaria com o disposto no art. 468: "A sentença, que julgar total ou parcialmente a lide, tem força de lei nos limites da lide e das questões decididas. ${ }^{15}$ "

A nosso ver, a opção do legislador, restringindo a coisa julgada ao comando contido na sentença se ajusta melhor ao princípio da demanda, também chamado princípio da iniciativa, que constitui princípio fundamental de nosso processo (CPC, art. $2^{\circ}$ ). Se a sentença é prolatada para de. cidir a respeito do pedido formulado pelo demandante, não há por que estender a

14. Contribuição à teoria da coisa julgada. pp. 133.

15. Contribuição à teoria da coisa julgada. pp. 133-43.

16. Contribuiçăo à teoria da coisa julgada. pp. 142-9. coisa julgada a fundamentos de outros possíveis pedidos, não formulados.

Adotada essa proposta do Autor, teriam as partes de, mesmo em processo de mínima importância, envidar o máximo de esforços para esclarecer cada fato alegado, temerosas de conseqüências imprevistas que poderiam resultar da verdade dos fatos estabelecida pela sentença.

\section{A quarta proposta}

A atenção volta-se aqui para as relações jurídicas continuadas. Considerem-se as hipóteses apresentadas: ${ }^{16}$

A primeira é de uma ação de cobrança de aluguéis, em que se defenda o locatário afirmando tratar-se de comodato. Preconiza o Autor a extensão dos limites objetivos da coisa julgada, para que restem abrangidos pela coisa julgada não somente o dispositivo, condenando o réu ao pagamento das prestações vencidas, mas também a declaração da natureza locatícia da relação. $\mathrm{O}$ caso não suscita qualquer problema no Direito vigente. Trata-se de caso clássico de cabimento de ação declaratória incidental.

A segunda hipótese apresentada pelo Autor é a de uma ação de consignação em pagamento proposta por mutuário do Sistema Financeiro da Habitação. Queixa-se PAULO ROBERTO DE OLIVEIRA LIMA de que não produzam coisa julgada os critérios estabelecidos pela sentença quanto à interpretação das regras contratuais concernentes aos critérios de reajustamento do valor das parcelas. Segundo nos parece, este também seria um caso solucionável mediante a propositura de ação declaratória incidental.

A terceira hipótese é a de um con trato de parceria agrícola, em que o primeiro parceiro entende de deduzir como despesa do empreendimento, antes da incidência do percentual destinado ao segundo parceiro, seus gastos pessoais, porquanto reside no imóvel. Decidida a lide em favor do segundo parceiro, o mesmo litígio pode se repetir em período subseqüente. Mais um caso que se resolve com a propositura de ação declaratória incidental.

A quarta hipótese diz respeito ao proprietário de um imóvel que pleiteia do vizinho permissão para ingressar no terreno deste, para reparos da parede divisória, situação que pode se repetir, dando origem a sucessivos litígios. Esse é um caso, que, a nosso ver, não se resolveria com qualquer declaração, por se tratar, na verdade, não de lide de pretensão resistida, mas de lide de pretensão insatisfeita. $O$ que se necessita é de um mandamento judicial e este não poderia senão ser concedido caso a caso.

Como se vê, as hipóteses imaginadas não sugerem a necessidade de alteração legislativa, como aliás reconhece o próprio Autor, nem, acrescentamos, novo enfoque doutrinário.

\section{Coisa julgada tributária}

Resta examinar, como última hipótese, a da coisa julgada tributária, que é as- sim exposta pelo Prof. HUGO DE BRITO MACHADO, em lição transcrita pelo $\mathrm{Au}$ tor:

"A relação jurídica tributária pode ser instantânea, como acontece no caso de venda eventual de um imóvel, por exemplo, ou continuativa, como acontece com o contribuinte do ICMS, por exemplo. No primeiro caso, o fato tributável é autônomo, isto é, nele residem todos os elementos de que necessita para determinar o valor do tributo a ser pago, e o pagamento extingue não apenas o crédito tributário respectivo, mas a própria relação obrigacional fiscocontribuinte. No segundo caso, o fato tributável não é autônomo, no sentido de que, embora produza, isoladamente, o efeito de criar a obrigação tributária, ele se insere em um conjunto de outros fatos relevantes para a composição da relação jurídica fisco-contribuinte.

A relação jurídica tributária instantânea é peculiar aos tributos relacionados com ocorrências eventuais. Por isto mesmo não existe, nem se faz necessário, um cadastro de contribuintes, sujeitos passivos desta relação.

A relação jurídica tributária continuativa é peculiar aos tributos relacionados a ocorrências que se repetem, formando uma atividade mais ou menos duradoura. Por isso mesmo os contribuintes, sujeitos passivos desta relação, inscrevem-se em cadastro específico, que se faz necessário precisamente em virtude da continuidade dos acontecimentos relevantes do ponto de vista tributário. Na relação jurídica continuativa, ou continuada, muitas vezes, até a determinação do valor a ser pago 
pelo contribuinte depende não apenas de um fato tributável, mas do encadeamento dos fatos que a integram, como acontece no Imposto sobre Produtos Industrializados (IPI), e no Imposto sobre Operações Relativas à Circulação de Mercadorias e Prestação de Serviços de Transporte Interestadual e Intermunicipal e de Comunicação (ICMS), tributos não cumulativos.

Realmente, no IPI, como no ICMS, o valor a ser pago em cada período é apurado em função de uma conta corrente, na qual são registrados débitos relativos às saídas de mercadorias e produtos e créditos, relativos às entradas de mercadorias ou de matérias-primas e outros insumos, no período de apuração respectivo.

A nosso ver, em se tratando de ação declaratória, não há dúvida de que a sentença que se reporte a relação jurídica continuativa produz efeitos para o futuro. A declaração da existência, da inexistência, ou do modo de ser de uma relação jurídica, neste caso, constitui o próprio dispositivo da sentença. E em se tratando de relação jurídica continuativa, esse dispositivo há de permanecer inalterado enquanto perdurar o estado de fato e a norma que com ele compõe a relação. ${ }^{17 "}$

Afirma PAULO ROBERTO que a jurisprudência praticamente unânime de nossos tribunais tem, entretanto, sufragado a tese oposta. Também a doutrina. A eventual aplicação da coisa julgada a fatos futu17. Hugo de Brito Machado. "Mandado de segurança em matéria tributária". Apud Paulo Roberto de Oliveira Lima. Contribuição à
teoria da coisa julgada. pp. 144-5.

18. Paulo Roberto de Oliveira Lima. Contribuição à teoria da coisa julgada. p. 146.

ros implicaria atribuir à sentença natureza normativa, o que é contrário à tradição de nosso direito processual e constitucional; o Judiciário não tem poder legiferante. A sentença não poderia senão resolver fatos já ocorridos quando de sua prolação.

"Trata-se de erro", diz PAULO ROBERTO OLIVEIRA LIMA. "Aliás, a mesma ciência que afirma tão categoricamente esta regra, deixa de enxergar, mercê de severa miopia jurídica, que, em muitas circunstâncias, consagra a solução diametralmente oposta, ou seja, há neste aspecto curioso fenômeno: pratica-se determinada regra, aplicando-a tranqüilamente em múltiplas hipóteses, e se anuncia solenemente princípio com ela incompatível. ${ }^{18 "}$

E com razão argumenta o Autor com a ação de alimentos que, na verdade, dispõe para o futuro, até porque in praeteritum non vivitur (não se vive no passado). Não valesse a sentença para o futuro, nova ação teria de ser proposta a cada mês, para determinar, por exemplo, o percentual da remuneração devido pelo alimentante.

Por que não se adota o mesmo critério relativamente às relações jurídicas tributárias de natureza continuada?

Cremos que há, realmente, identidade de situações, de que não se dão conta aqueles que negam a existência de coisa julgada em ação de alimentos.

É exato que o juiz julga fatos passados; quando muito, fatos atuais. Isso, po-

Revista da Faculdade de Direito da UFRGS, v. 17, 1999 rém, não quer dizer que a sentença não disponha para o futuro. Assim como a lei, também a sentença se destina a regular a conduta humana e não se regula senão para o futuro. A sentença que condena permite que, no futuro, o vencedor promova a execução; a sentença que constitui, não raro constitui ex nunc, ou seja, somente para o futuro. A sentença mandamental determina que algo se faça ou não se faça no futuro. Por que não se poderia declarar para o futuro? Uma razão possível seria a vinculação, que restaria por demonstrar, entre declaração e condenação. Nada se poderia declarar com relação a prestações vincendas, porque só possível condenação com relação a prestações vencidas. Mas o que é uma sentença declaratória da paternidade senão uma declaração para ser respeitada no futuro? A declaração judicial de paternidade não constitui declaração de mero fato, ocorrido no passado, o fato biológico da concepção, mas declaração de relação jurídica, que não tem outro sentido que o de impor o respeito, no futuro, aos efeitos jurídicos decorrentes dessa declaração.

Todavia, o efeito de coisa julgada em matéria tributária, como em matéria administrativa, pode ter um efeito perverso, que explica a jurisprudência criticada por PAU. LO ROBERTO DE OLIVEIRA LIMA.

Suponha-se que da interpretação de dispositivo legal decorra declaração judici al de que tal ou qual contribuinte tem direito à isenção ou redução de alíquota nas operações de circulação de mercadorias que realiza habitualmente. Por divergência jurisprudencial, outro contribuinte, embo-

19. Contribuiçăo à teoria da coisa julgada. p. 158. ra em situação idêntica, obtém exatamente declaração contrária. Em face da imutabilidade da coisa julgada, perpetuarse-ia a igualdade de tratamento, enquanto não alterada a lei interpretada?

\section{Coisa julgada e servidores públicos}

Um outro exemplo, este no âmbito do Direito Administrativo, é dado pelo mesmo PAULO ROBERTO OLIVEIRA LIMA, com relação a servidores públicos:

"Em face do momento em que foram propostas e julgadas, algumas ações terminaram com a concessão de $84,32 \%$ de reajuste, em março de 1990, aos autores, servidores públicos. Tendo o Supremo Tribunal Federal, mais tarde, cifrado o entendimento de que tal reajuste não era devido, outras tantas ações terminaram por negar aos autores, servidores públicos, igual vantagem. Ironicamente, em muitos casos, ambas as sentenças transitaram em julgado, tendo decorrido in albis o prazo da rescisória. Em face das regras hoje adotadas, disciplinadoras do instituto da coisa julgada, a situação será definitivamente mantida, ou seja, na mesma 'repartição pública' servidores exercentes de cargo igual receberão eternamente remunerações diferentes. $\mathrm{O}$ fato implica irretorquível agressão ao princípio constitucional da isonomia, macula os cânones máximos do Direito Administrativo (impessoalidade, indisponibilidade, legalidade fechada) e agride ao senso comum de justiça, daí porque desserve ao Direito. $O$ respeito à coisa julgada não justifica tamanho sacrifício!! ${ }^{19 "}$ 
O caso dos servidores públicos é mais complexo, face à irredutibilidade de vencimentos consagrada pela Constituição (art., $37, \mathrm{XV})$.

Mas para a relação jurídica tributária já temos, em nosso sistema, um princípio de solução. Encontra-se no art. 471, I, do CPC, que prevê a alteração do julgado, nas relações jurídicas continuativas, havendo alteração no estado de fato ou de direito.

\section{Nossa proposta: uma nova hipótese de revisão de sentença}

Para nós, que entendemos que a ju risprudência constitui, sim, fonte de direi to, esse dispositivo contém a solução do problema. Se o contribuinte (ou o Fisco) obtém declaração, com base em determinada interpretação, mas a jurisprudência vem a se fixar em sentido oposto, há de caber a revisão do julgado, porque houve modificação do Direito.

Esta é, pois, a nossa primeira proposta: que se inclua, no art. 471, parágrafo es clarecendo que se considera modificação no estado de direito a fixação da jurisprudência em outro sentido, por súmula do tribunal competente (que seria o Supremo Tribunal Federal, em matéria constitucional; o Superior Tribunal de Justiça, quanto a lei federal; o Tribunal de Justiça, no que diz respeito a lei local). Observe-se que não se estaria a rescindir a sentença. A ação seria rigorosamente de revisão do julgado, com efeitos ex nunc ou retroagindo, no máximo, à data da propositura da ação revisional.
Como já se observou, no caso das lides de servidores públicos com a Administração, o problema se apresenta mais complexo, porque certamente se entenderia que a revisão do julgado não poderia implicar redução de vencimentos, face à irredutibilidade estabelecida pela Constituição. E a rescisão poderia encontrar obstáculo na Súmula no 343 do STF ("Não cabe ação rescisória por ofensa a literal disposição de lei, quando a decisão rescindenda se tiver baseado em texto legal de interpretação controvertida nos tribunais"), embora se tenha excetuado dessa regra as controvérsias envolvendo matéria constitucional:

"Nada importa a circunstância de ter sido controvertida pelos tribunais a compatibilidade entre a constituição e a lei: a restrição contida na Súmula n 343 do ST] incide somente, quando o acórdão enveredou pela interpretação do dispositivo legal". (Brasília, STJ, 1 - Turma, REsp 132.314/PE, Ministro HUMBERTO GOMES DE BARROS, Relator, 25.08.1998. DJU 28/09/ 1998 , p. 00010). "Se a decisão judicial rescindenda aplicou lei cuja inconstitucionalidade veio a ser declarada pelo Supremo Tribunal Federal, a ação rescisória é cabível. Nada importa a circunstância de que, na época em que se formou tal decisão, era controvertida nos tribunais a compatibilidade entre a constituição e a lei: a restrição contida na Súmula no 343 , do STF, incide somente quando o dissídio pretoriano envolvia a interpretação do dispositivo legal.(Brasília, STJ, REsp 130.886/ RS, Ministro HUMBERTO GOMES DE BARROS, Relator, 18.08.1998. DJU 13.10.1998, p. 00017). "Se o Pretório Excelso declarou inconstitucional lei que, antes, o acórdão havia reputado válida, o julgado deste deve ser rescindido ainda que, à época, o tema fosse controvertido" STF Súmula no 343). Recurso especial conhecido e provido.(Brasília, STJ, REsp 163.999/ RS, Ministro ARI PARGENDLER, 03.09.1998. DJU 28.09.1998, p. 00040).

A rescisão do julgado poderia, ainda, encontrar obstáculo na proposta que formulamos. Efetivamente, havida como alteração do Direito a fixação da jurisprudência em determinado sentido, por súmula do tribunal competente, não poderia ser ela invocada para rescindir sentenças a ela anteriores.

Sem negar a força do argumento, res ponderíamos que, embora se considere também a jurisprudência como fonte do Direito, não se nega a supremacia da Lei. A fixação da jurisprudência em determinado sentido supõe controvérsia jurisprudencial. A edição de súmula não significa inovação no Direito, igual à da lei, mas inovação apenas para que interpretavam a lei em sentido diverso. Certo, não seria de se rescindir sentença por contrariar súmula posteriormente editada; mas cabível a rescisão por violação de literal disposição de lei já vigente à data dos fatos julgados pela sentença.

Quando mais não seja, porém, a rescisão poderia encontrar obstáculo na decadência, pelo decurso do prazo bienal.

\section{Coisa julgada e \\ irredutibilidade de \\ vencimentos}

Consideremos as hipóteses que podem surgir, com relação aos servidores pú- blicos, em face de texto legal de interpretação controvertida.

Se a jurisprudência vem a se fixar em sentido favorável aos servidores, os que não propuseram ação poderão, a qualquer tempo, propor a sua ação, porque, salvo negativa expressa da Administração, a prescrição só alcançará as prestações vencidas há mais de cinco anos; os que propuseram ação, mas foram vencidos, poderão ver restabelecida a isonomia, através de lei ou ato administrativo que lhes estenda o benefício negado por sentença.

Se a jurisprudência vem a se fixar em sentido favorável à Administração, esta poderá, quando muito, obter a rescisão das sentenças em que foi vencida, propondo ação rescisória, no prazo de dois anos contados do trânsito em julgado de cada decisão. Como, via de regra, a jurisprudência leva mais de dois anos, para se fixar em determinado sentido, haverá servidores que, por força de sentença errada (segundo essa mesma jurisprudência), receberão vantagem indevida, por tempo indeterminado e em flagrante quebra do princípio da isonomia. A revisão da sentença, tal como preconizamos, não será possível, face ao princípio da irredutibilidade de vencimentos.

Aliás, a proposta que formulamos, poderá até reforçar sua posição. Efetivamente, se a fixação da jurisprudência em determinado sentido constitui alteração do Direito, é claro que por ela não poderão ser prejudicados, como não poderiam sê-lo por lei nova. Assim, a regra da irredutibilidade de vencimentos poderia ser esgrimida tanto para excluir a revisão quanto a rescisão da sentença. 
Parece-nos injusta a quebra do princípio da isonomia, ainda que em nome do respeito à coisa julgada. Além do prejuízo ao erário, que não deve ser desprezado, escandaliza a permanência no tempo de uma situação evidentemente contrária ao prin cípio fundamental da isonomia. Para o problema não vemos, todavia, outra solução do que uma reforma constitucional, que acrescente mais uma exceção à regra da irredutibilidade de vencimentos, qual seja a de que ela não impedirá a revisão do julgado, quando a jurisprudência houver se fixado em sentido diverso.

\section{Acórdão comentado}

Freqüentemente, é a jurisprudência que explica textos legais de interpretação duvidosa. Primeiro é editada a lei, sobrevêem depois acórdãos que a explicam. Por certo, não se pode invocar jurisprudência para explicar texto legal futuro.

Invertendo, todavia, essa ordem lógica, referimos e comentamos a segui acórdão do Tribunal de Justiça do Rio Grande do Sul ${ }^{20}$, para melhor explicar o sentido da proposta que estamos a oferecer.

Aberto concurso público para ingresso em Curso Superior de Formação de Delegado de Polícia, foram os candidatos submetidos a teste de capacitação física. Alguns dos reprovados nesse teste propuseram ação, sustentando sua ilegalidade com variada argumentação: porque único, porque eliminatório, por se tratar de exigência revogada pela Constituição do Estado, por mal conduzido, etc. Todos

obtiveram êxito, menos um, porque julgado por Câmara que adotou orientação diversa da que veio a final a prevalecer no Tribunal.

Por força de liminar, esse candidato havia feito o curso e recebido o diploma de conclusão. Embora considerado física e mentalmente apto pelo Serviço de Biometria Médica, não foi nomeado para o cargo de Delegado, porque a sentença definitiva não lhe foi favorável.

Propôs, então, nova ação, pedindo sua aprovação no referido concurso, tendo em vista a declaração, em processos similares, da nulidade do teste de aptidão física em que fora reprovado.

A sentença de $1^{\circ}$ grau, bem como a maioria dos desembargadores que julgaram a apelação, reconheceram a existência de coisa julgada. O relator encontrou certa dificuldade no reconhecimento da identidade de causa de pedir e de pedido: quanto à causa de pedir, porque fundada a ação no princípio da isonomia; quanto ao pedido, por visar à nomeação, quando antes se buscara apenas a declaração de aprovação no teste. Entendemos que a invocação do princípio da isonomia representou apenas um argumento a mais, não uma nova causa de pedir, porque esta decorre dos fatos, conforme a teoria da substanciação, adotada por nosso Código. $O$ pedido novo, de nomeação, não poderia ser deferido sem afastar-se o obstáculo da sentença anterior, que confirmara a decisão administrativa, declarando-o reprovado no teste de aptidão física.

20. Porto Alegre, Tribunal de Justiça do Rio Grande do Sul, $3^{\mathrm{a}}$ Câmara Cível, AC 595160656, Araken de Assis, Relator, 19.12.1996.
Pareceu, também, ao relator, não haver identidade de fatos, entre a situação do autor, vencido, e dos vencedores dos demais processos: "O fato de alguém ter sido aprovado, em outros concursos, na mesma prova de aptidão física, não induz, como parece óbvio, à dispensa e/ou à aprovação em prova ulterior". Sem dúvida, a aptidão física constitui condição individual, que pode ser afirmada com relação a alguns e negada com relação a outros, sem quebra de qualquer princípio jurídico. No caso, porém, houve realmente tratamento diferenciado, não obstante identidade de fatos, porque os paradigmas foram dispensados da exigência de aprovação no teste de aptidão física, o que não ocorreu com o autor.

\section{$O$ voto vencido}

Via de regra, o que importa são os votos vencedores, que são os que exprimem o pensamento do tribunal. Aqui, porém, prestamos especial atenção ao voto vencido, prolatado pelo eminente Desembargador MOACIR ADIERS, por haver preconizado a rescisão da sentença, por ação ordinária, face à circunstância de haver a jurisprudência se fixado em outro sentido. Solução, como se vê, com alguma semelhança com a que preconizamos de jure condendo (ou seja, a proposta para o Direito futuro).

Do ponto de vista do direito posto, o voto vencido apresenta-se como contradi tório e violador da lei. Contraditório, por haver afirmado o cabimento de ação rescisória, reconhecendo, assim, a existên- cia de coisa julgada, para negá-la, depois, "temperando-a". Violador da lei, por haver desprezado a coisa julgada, afastando o princípio da legalidade estrita, invocando a equidade, que o Código de Processo Civil somente admite nos casos previstos em lei (art. 127).

Mas não é do ponto de vista da legalidade que esse voto merece nossa atenção, o que importa assinalar é que pretendeu rescindir a sentença, por ação ordinária, sob o fundamento de haver a jurisprudência se fixado em sentido diverso. Por igual fundamento estamos a propor a revisão das sentenças.

Há, porém, uma profunda diferença entre a proposta contida no voto vencido e a nossa. É que propomos a revisão apenas com relação às relações continuativas e com efeitos ex nunc. Ora, a revisão de sentença incidente sobre relação jurídica continuativa não implica desrespeito à coisa julgada, como já o demonstraram, entre outros, ADROALDO FURTADO FABRÍ. CIO e ARAKEN DE ASSIS, ao tratar das ações de alimentos. ${ }^{21}$

A proposta do voto vencido foi de rescisão da sentença, desconstituindo-se seus efeitos ex tunc. Isso, a nosso ver, somente é admissível por ação rescisória. E não podia a Câmara julgar a apelação como ação rescisória até mesmo porque absolutamente incompetente (no Rio Grande do Sul, compete aos Grupos Cíveis processar e julgar as ações rescisórias de acórdãos de suas Câmaras).

21. Araken de Assis. Breve contribuição ao estudo da coisa julgada nas açóes de Alimentos. Porto Alegre, Ajuris, (46): 77-96, jul.89. Adroaldo Furtado Fabricio. A coisa julgada na ação de alimentos. Ajuris, Porto Alegre, (52): 5-33, jul. 91. 
Serve, assim, a hipótese, para melhor esclarecer os limites de nossa proposta, que $\operatorname{diz}$ respeito apenas às relações jurídicas continuativas.

Como já se observou, o voto vencido afastava o princípio da legalidade, para que prevalecesse a justiça.

Embora o tema da justiça fuja aos propósitos do presente trabalho, ousamos pôr em dúvida sua assertiva de que houve "flagrante injustiça".

O que há de mais importante em um concurso é a rigorosa observância das normas que o disciplinam. De modo algum se admite a "alteração das regras do jogo", depois de se verificar que estes ou aqueles candidatos resultaram eliminados. Os que venceram todas as provas têm direito a prosseguir no concurso já sem a concorrência dos reprovados. Se a Administração estatui que certa prova "não valeu", para dar nova oportunidade a alguns assim favorecidos, há ilícito administrativo. Deixa de haver tratamento igual de todos os candidatos, quando se dispensam alguns da exigência de aprovação em prova exigida de todos os outros.

Do ponto de vista de justiça, a situação não muda, se a "alteração das regras do jogo" decorre de sentença.

Claro que o Judiciário pode anular ou dispensar prova, em atenção ao princípio da legalidade. Mas, sempre visualizando a situação do ponto de vista dos prejudicados pela decisão judicial: seriam prejudicados, primeiro, pela invocação do princípio da legalidade, com a reintrodução no concurso de candidatos que, observado o edital, já estariam afastados; depois, pela desconsideração da legalidade, em especial pelo desrespeito à coisa julgada, com a reintrodução de ainda outro, agora com invocação de princípio de justiça.

"Que estranho poder tem esse candidato!", bem poderiam exclamar, "de afastar prova de nós exigida, com invocação do princípio da legalidade, e de afastar o mesmo princípio, quando o prejudicava!"

Evidencia-se, assim, que a "flagrante injustiça", apontada pelo vencido, somente é sentida na medida em que nos identificamos com o autor da ação; não quando consideramos os fatos do ponto de vista do todo maior dos demais concorrentes. Trata-se, pois, de uma justiça meramente subjetiva, em oposição à justiça objetiva, entendida esta como "conformidade de uma relação interpessoal com o bem comum", tal como a definia o jusfilósofo gaúcho ARMANDO CÂMARA.

Se valessem considerações de justiça subjetiva, bem que poderíamos nos colocar no lugar daquele concorrente ausente, que deixaria de ser nomeado, porque preterido uma vez por causa da lei, e outra contra a lei.

No plano legal, a ação rescisória não se presta à correção de injustiça da sentença. Com mais forte razão, não se pode dispensar a própria ação rescisória, para corrigir injustiça de sentença anterior. Se, num caso, invocamos o princípio da isonomia, para afastar essas regras, como aplicá-las nos outros, sem quebra do mesmo princípio da isonomia? E, se as afastamos em todos os casos, deixa de haver "coisa julgada", com todos os benefícios que dela decorrem.

\title{
Dimensões da Independência do Poder Judiciário
}

\author{
Fosé eNéri da Pilveina \\ Ministro do Supremo Tribunal Federal
}

Aula Magna proferida na Faculdade de Direito da Universidade Federal do Rio Grande do Sul, a 26.04.1999, em Porto Alegre, RS.

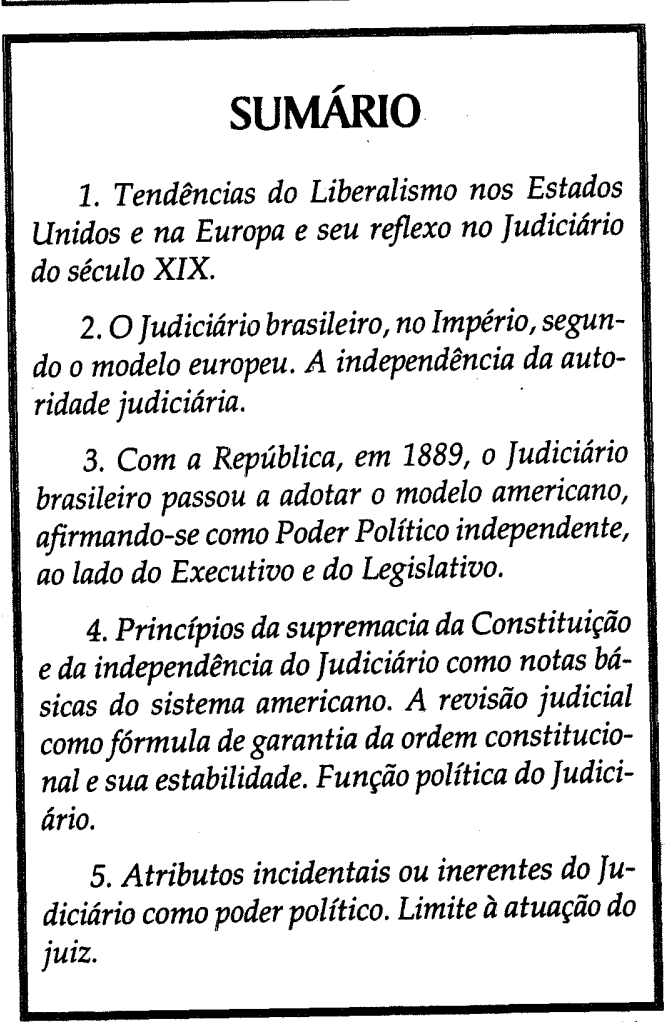

6. Autonomia administrativa e financeira como nova dimensão da independência do Poder Judiciário, desde a Constituição de 1988. Autonomia administrativa e unidade do Poder Judiciário. Necessidade de um Conselho Nacional de Administração da Justiça.

7. A legitimidade do Poder Judiciário expressa em disciplina constitucional.

8. A visualização teleológica do Poder Judiciário, enquanto instrumento de efetiva realização da cidadania e de real garantia dos direitos.

9. Universalidade do controle jurisdicional. O processo e sua instrumentalidade. O processo e a justiça social. O acesso à Justiça para todos.

10. Os pobres e o acesso d̀ justiça. A essencialidade da Defensoria Pública, na administração da Justiça.

11. O controle dos atos do Poder Judiciário. O controle e o princípio da independência do Judiciário.

12. Reforma constitucional do Judiciário e a cláusula pétrea do art. $60, \S 4^{\circ}$, III, da Constituição. Limites materiais.

13. A independência do Judiciário como valor indisponivel. 